Endokrynologia Polska DOI: 10.5603/EP.2013.0012 Tom/Volume 64; Numer/Number 4/2013 ISSN 0423-104X

\title{
Practical guidelines for the supplementation of vitamin $D$ and the treatment of deficits in Central Europe - recommended vitamin $D$ intakes in the general population and groups at risk of vitamin D deficiency
}

Wytyczne suplementacji witaminą D dla Europy Środkowej — rekomendowane dawki witaminy D dla populacji zdrowej oraz dla grup ryzyka deficytu witaminy D

Paweł Płudowski', Elżbieta Karczmarewicz', Milan Bayer'², Graham Carter ${ }^{3}$, Danuta Chlebna-Sokól', Justyna Czech-Kowalska ${ }^{5}$, Romuald Dębski ${ }^{6}$, Tamas Decsi ${ }^{7}$, Anna Dobrzańska ${ }^{5}$, Edward Franek ${ }^{8}$, Piotr Głuszko 9,10, William B. Grant ${ }^{11}$, Michael F. Holick ${ }^{12}$, Liudmila Yankovskaya ${ }^{13}$, Jerzy Konstantynowicz ${ }^{14}$, Janusz B. Książyk ${ }^{15}$, Krystyna Księżopolska-Orłowska ${ }^{16}$, Andrzej Lewiński ${ }^{17}$, Mieczysław Litwin ${ }^{18}$, Szimonetta Lohner ${ }^{6}$, Roman S. Lorenc ${ }^{1}$, Jacek Łukaszkiewicz ${ }^{19}$, Ewa Marcinowska-Suchowierska ${ }^{20}$, Andrzej Milewicz ${ }^{21}$, Waldemar Misiorowski ${ }^{22}$, Michał Nowicki ${ }^{23}$, Vladyslav Povoroznyuk ${ }^{24}$, Piotr Rozentryt ${ }^{25}$, Ema Rudenka ${ }^{26}$, Yehuda Shoenfeld ${ }^{27}$, Piotr Socha ${ }^{28}$, Bogdan Solnica ${ }^{29}$, Mieczysław Szalecki ${ }^{30,}{ }^{31}$, Marek Tałałaj ${ }^{20}$, Szabolcs Varbiro ${ }^{32}$, Michał A. Żmijewski ${ }^{33}$

${ }^{1}$ Department of Biochemistry, Radioimmunology and Experimental Medicine, The Children's Memorial Health Institute, Warsaw, Poland

${ }^{2}$ Department of Paediatrics, Charles University Prague, Faculty of Medicine in Hradec Kralove, University Hospital Hradec Kralove, Czech Republic

${ }^{3}$ Imperial College Healthcare NHS Trust, Charing Cross Hospital, London, United Kingdom

${ }^{4}$ Department of Propaedeutics of Paediatrics, Medical University of Lodz, Lodz, Poland

${ }^{5}$ Department of Neonatology and Neonatal Intensive Care, The Children's Memorial Health Institute, Warsaw, Poland

${ }^{6}$ II Department of Gynaecology and Obstetrics, Medical Centre for Postgraduate Education, Warsaw, Poland

${ }^{7}$ Department of Paediatrics, University of Pecs, Pecs, Hungary

${ }^{8}$ Department of Internal Diseases, Endocrinology and Diabetology, Central Clinical Hospital MSWiA, Department of Human

Epigenetics, Medical Research Centre, Polish Academy of Sciences, Warsaw, Poland

${ }^{9}$ Department of Rheumatology, Institute of Rheumatology, Warsaw, Poland

${ }^{10}$ Andrzej Frycz Modrzewski Krakow University, Krakow, Poland

${ }^{11}$ Sunlight, Nutrition and Health Research Centre, San Francisco, CA, United States

${ }^{12}$ Department of Medicine, Section of Endocrinology, Nutrition, and Diabetes Vitamin D, Skin and Bone Research Laboratory,

Boston University Medical Centre, Boston, MA, United States

${ }^{13}$ Polyclinic Therapy Department, Grodno State Medical University, Grodno, Belarus

${ }^{14}$ Department of Paediatrics and Developmental Disorders, Medical University of Bialystok, Bialystok, Poland

${ }^{15}$ Department of Paediatrics, The Children's Memorial Health Institute, Warsaw, Poland

${ }^{16}$ Department of Rheumatologic Rehabilitation, Institute of Rheumatology, Warsaw, Poland

${ }^{17}$ Department of Endocrinology and Metabolic Diseases, Polish Mother's Memorial Hospital — Research Institute, Medical

University of Lodz, Lodz, Poland

${ }^{18}$ Department of Nephrology, Kidney Transplantation and Arterial Hypertension, The Children's Memorial Health Institute, Warsaw, Poland

${ }^{19}$ Department of Biochemistry and Clinical Chemistry, Medical University of Warsaw, Warsaw, Poland

${ }^{20}$ Department of Family Medicine, Internal and Metabolic Bone Diseases. Medical Centre for Postgraduate Education,

Warsaw, Poland

${ }^{21}$ Department of Endocrinology, Diabetology and Isotope Therapy, Wroclaw Medical University, Wroclaw, Poland

${ }^{22}$ Endocrinology Department, Medical Centre for Postgraduate Education, Warsaw, Poland

${ }^{23}$ Department of Nephrology, Hypertension, and Kidney Transplantation, Medical University of Lodz, Lodz, Poland

${ }^{24}$ D.F. Chebotarev Institute of Gerontology of National Academy of Medical Sciences of Ukraine, Kiev, Ukraine

${ }^{25}$ Third Department of Cardiology, Silesian Centre for Heart Disease, Silesian Medical University, Zabrze, Poland

${ }^{26}$ Belarusian Medical Academy of Post-graduate Education, Minsk, Belarus

${ }^{27}$ Zabludowicz Centre for Autoimmune Diseases, Sheba Medical Centre, Tel Hashomer Affiliated with Tel Aviv University, Faculty of Medicine, Israel

Paweł Płudowski M.D., Department of Biochemistry, Radioimmunology and Experimental Medicine, The Children's Memorial Health Institute, Aleja Dzieci Polskich 20, 04-740 Warszawa, Polska, tel.: +48 22815 17 76, e-mail: p.pludowski@czd.pl 
${ }^{28}$ Department of Gastroenterology, Hepatology and Eating Disorders, The Children's Memorial Health Institute, Warsaw, Poland

${ }^{29}$ Department of Diagnostics, Jagiellonian University Medical College, Krakow, Poland

${ }^{30}$ Department of Endocrinology and Diabetology, The Children's Memorial Health Institute, Warsaw, Poland

${ }^{31}$ Faculty of Health Science, UJK, Kielce, Poland

${ }^{32}$ Semmelweis University, Faculty of Medicine, 2nd Department of Obstetrics and Gynaecology, Budapest, Hungary

${ }^{33}$ Department of Histology, Medical University of Gdansk, Gdansk, Poland

\begin{abstract}
Introduction: Adequate Vitamin D intake and its concentration in serum are important for bone health and calcium-phosphate metabolism as well as for optimal function of many organs and tissues. Documented trends in lifestyle, nutritional habits and physical activity appear to be associated with moderate or severe Vitamin D deficits resulting in health problems. Most epidemiological studies suggest that Vitamin D deficiency is prevalent among Central European populations. Concern about this problem led to the organising of a conference focused on overcoming Vitamin D deficiency.

Methods: After reviewing the epidemiological evidence and relevant literature, a Polish multidisciplinary group formulated theses on recommendations for Vitamin D screening and supplementation in the general population. These theses were subsequently sent to Scientific Committee members of the 'Vitamin D - minimum, maximum, optimum' conference for evaluation based on a ten-point scale. With 550 international attendees, the meeting 'Vitamin D - minimum, maximum, optimum' was held on October 19-20, 2012 in Warsaw (Poland). Most recent scientific evidence of both skeletal and non-skeletal effects of Vitamin D as well as the results of panellists' voting were reviewed and discussed during eight plenary sessions and two workshops.

Results: Based on many polemical discussions, including post-conference networking, the key opinion leaders established ranges of serum 25-hydroxyVitamin D concentration indicating Vitamin D deficiency $[<20 \mathrm{ng} / \mathrm{mL}(<50 \mathrm{nmol} / \mathrm{L})]$, suboptimal status [20-30 ng/mL $(50-75 \mathrm{nmol} / \mathrm{L})]$, and target concentration for optimal Vitamin D effects [30-50 ng/mL $(75-125 \mathrm{nmol} / \mathrm{L})]$. General practical guidelines regarding supplementation and updated recommendations for prophylactic Vitamin D intakes in Central European neonates, infants, children and adolescents as well as in adults (including recommendations for pregnant and breastfeeding women and the elderly) were developed. Conclusions: Improving the Vitamin D status of children, adolescents, adults and the elderly must be included in the priorities of physicians, healthcare professionals and healthcare regulating bodies. The present paper offers elaborated consensus on supplementation guidance and population strategies for Vitamin D in Central Europe. (Endokrynol Pol 2013; 64 (4): 319-327)
\end{abstract}

Key words: vitamin D deficiency, 25-hydroxyvitamin-D, general population guidelines, risk groups, Central Europe, supplementation

\title{
Streszczenie
}

Wstęp: Wyniki badań z ostatnich lat dokumentują wiele korzyści wynikających z działania witaminy D na organizm człowieka na wszystkich etapach jego życia. Większość badań epidemiologicznych sugeruje, że niedobór witaminy D jest powszechny wśród mieszkańców Europy Środkowej. Naturalną konsekwencją tej sytuacji jest konieczność ciągłego uświadamiania społeczeństwu oraz środowisku medycznemu, jaką rolę odgrywa witamina D w rozwoju i funkcjonowaniu organizmu ludzkiego.

Metody: Na podstawie przeglądu danych literaturowych Polski Zespół Wielodyscyplinarny opracował tezy dotyczące zasad suplementacji witaminą D, które przesłano do członków Komitetu Naukowego konferencji „Witamina D — minimum, maksimum, optimum”, 19-20 Październik, 2012, Warszawa. W trakcie powyższej konferencji z udziałem 550 delegatów oraz Ekspertów różnych dziedzin medycyny omówiono i przedyskutowano propozycje wytycznych suplementacji witaminą D populacji Europy Środkowej.

Wyniki. W efekcie przeprowadzonych dyskusji Zespół Ekspertów opracował wytyczne suplementacji witaminą D dla wszystkich grup wiekowych populacji Europy Środkowej. Określono również kryteria diagnostyczne charakteryzujące stan zaopatrzenia organizmu w witaminę D: deficyt witaminy D ustalono jako stężenie $25(\mathrm{OH}) \mathrm{D}<20 \mathrm{ng} / \mathrm{mL}(<50 \mathrm{nmol} / \mathrm{L})$ ], suboptymalne zaopatrzenie jako stężenie $25(\mathrm{OH}) \mathrm{D}$ wynoszące $20-30 \mathrm{ng} / \mathrm{mL}$ (50-75 nmol/L), a stężenie $30-50 \mathrm{ng} / \mathrm{mL}$ (75-125 nmol/L) uznano za docelowe dla zapewnienia efektu plejotropowego witaminy D.

Wnioski. Poprawa obecnego stanu zaopatrzenia witaminy D w grupach dzieci, młodzieży, osób aktywnych zawodowo i seniorów powinna zostać włączona do priorytetów polityki zdrowotnej społeczeństw Europy Środkowej. (Endokrynol Pol 2013; 64 (4): 319-327)

Słowa kluczowe: niedobór witaminy D, 25-hydroksywitamina D, wytyczne populacyjne, grupy ryzyka, suplementacja

\section{Introduction}

Recent reports have found several positive effects of Vitamin D for humans of all ages. Until recently, deficits of Vitamin D were associated mostly with the risk of developing rickets [1]. Current research, however, considers reduced Vitamin D concentration as a potential significant risk factor for diseases such as cancer [2-4], cardiovascular disease [5-7], diabetes [8-10], hypertension [11-13], autoimmune diseases [14-16], metabolic disorders [17, 18], infectious diseases caused by decreased immunity [19], and some neuropsychiatric conditions [20]. An increasing body of evidence of Vitamin D's beneficial effects prompted the development of nationwide recommendations to prevent
Vitamin D deficiency in Poland (2009), Hungary (2012) and Germany-Austria-Switzerland (2012) [21-23]. Furthermore, the Institute of Medicine of the U.S. National Academies published 'Dietary Reference Intakes for Calcium and Vitamin D' (2010) which were extensively discussed by the Endocrine Society which issued its own guidelines (2011) [24, 25]. In 2010, the International Osteoporosis Foundation released a position paper on recommendations for Vitamin D nutrition in elderly men and women [26]. In 2012, the European Food Safety Authority released the revised Tolerable Upper Intake Levels (upper limits [ULs]) of Vitamin D for all relevant population groups [27]. Unfortunately, despite available recommendations on Vitamin D supplementation and its ULs, daily Vita- 
min $\mathrm{D}$ intake is rigorously preserved only during the first months of life; later in life, Vitamin D is given only occasionally, if at all. The evident consequence is low average Vitamin D concentration among populations of Central Europe, indicating a need for continuous awareness by the public and the medical community. Adequate Vitamin D status is associated with the overall health of infants, children, adolescents, professionally active people and the elderly. By contrast, inadequate Vitamin D concentration (even if considered an epiphenomenon) is frequently noted in patients suffering from a wide spectrum of diseases [1-20].

The Vitamin D doses recommended here are based on both well-documented skeletal effects and an increasing number of well-designed studies suggesting extra-skeletal effects. These recommendations apply not only in the context of preventing rickets or osteoporosis, but also in a broader context of preventive action against many disorders and morbidities that affect people of all ages. The main goal of proper Vitamin D supplementation is to ensure an adequate serum 25-hydroxyVitamin $\mathrm{D}[25(\mathrm{OH}) \mathrm{D}]$ concentration and, thereby, to guarantee short- and long-term effects, with appropriate safety considerations.

\section{Sources of Vitamin D}

Adequate Vitamin D intake, positive calcium balance and outdoor physical activity i.e. weight-bearing exercise are essential for appropriate skeletal growth and bone mineralisation. These environmental factors also show a liability to reduce risk of several diseases. A diverse diet rich in food containing large amounts of Vitamin D, including oily fish, is important (Table I). If the additive effect of dietary Vitamin D consumption and sunlight-induced Vitamin D synthesis in the skin is insufficient, taking supplements becomes essential to achieve optimal Vitamin D status. Because the circulating metabolite of Vitamin D has a long serum half-life (4-6 weeks) and is stored in tissues, Vitamin D can be administered other than once per day - for example, every other day, twice per week, or once weekly. This flexibility answers the technical problems of dividing drops and the higher-than-required dose of available commercial preparations.

Most Vitamin D in the human body is produced in the skin after exposure to sunlight, specifically solar ultraviolet-B irradiance. Sunscreens, which are widely used in Europe during the summer, may reduce skin synthesis by $90-95 \%$ [28]. In Central Europe, solar angle and weather conditions suitable for Vitamin D synthesis occur between late April and early September; whereas skin synthesis does not occur from
Table I. Sources of vitamin D

Tabela I. Źródta witaminy D

\begin{tabular}{lc}
\hline Source & Vitamin d content \\
\hline Cod liver oil & $\sim 400-1,000 \mathrm{IU} / \mathrm{tsp}$ \\
\hline Eel, fresh & $\sim 1,200 \mathrm{IU} / 100 \mathrm{~g}$ \\
\hline Salmon, fresh wild caught & $\sim 600-1,000 \mathrm{IU} / 100 \mathrm{~g}$ \\
\hline Herring in oil & $\sim 800 \mathrm{IU} / 100 \mathrm{~g}$ \\
\hline Pickled herring & $\sim 480 \mathrm{IU} / 100 \mathrm{~g}$ \\
\hline Salmon, fresh farmed & $\sim 100-250 \mathrm{IU} / 100 \mathrm{~g}$ \\
\hline Salmon, tinned & $\sim 300-600 \mathrm{IU} / 100 \mathrm{~g}$ \\
\hline Sardines, tinned & $\sim 300 \mathrm{IU} / 100 \mathrm{~g}$ \\
\hline Mackerel, tinned & $\sim 250 \mathrm{IU} / 100 \mathrm{~g}$ \\
\hline Tuna, tinned & $\sim 230 \mathrm{IU} / 100 \mathrm{~g}$ \\
\hline Shiitake mushrooms, fresh & $\sim 100 \mathrm{IU} / 100 \mathrm{~g}$ \\
\hline Egg yolk & $\sim 20-50 \mathrm{IU} / \mathrm{yolk}$ \\
\hline Cheese & $\sim 7-28 \mathrm{IU} / 100 \mathrm{~g}$ \\
\hline Breast milk & $\sim 1.5-8 \mathrm{IU} / 100 \mathrm{~mL}$ \\
\hline Cow's milk & $\sim 0.4-1.2 \mathrm{IU} / 100 \mathrm{~mL}$ \\
\hline Milk-corny gruels & $\sim 60-80 \mathrm{IU} / 100 \mathrm{~mL}$ \\
\hline Infant formula (beginning formula) & $\sim 40-50 \mathrm{IU} / 100 \mathrm{~mL}$ \\
\hline Infant formula (follow-up formula) & $\sim 40-80 \mathrm{IU} / 100 \mathrm{~mL}$ \\
\hline Formula for children aged 12 months & $\sim 70-80 \mathrm{IU} / 100 \mathrm{~mL}$ \\
\hline or older & $\begin{array}{l}\text { Skin synthesis/UVB radiation } \\
\text { Skitamin D3. }\end{array}$ \\
\hline & equivalent of $\sim 2,000-4,000 \mathrm{IU}$ \\
\hline
\end{tabular}

October to March [29]. The efficacy of skin synthesis basically depends on two factors: the degree of skin pigmentation and age. For optimal effect, Central Europeans should expose, without sunscreen, $18 \%$ of the body surface (i.e. uncovered forearms and partially exposed legs) to a half of one minimal erythemal dose (MED, defined as slight reddening of skin $24 \mathrm{~h}$ post exposure) two or three times per week. In practical terms, exposing $18 \%$ of the body to the sun without sunscreen for approximately 15 minutes a day between $10 \mathrm{a} . \mathrm{m}$. and $3 \mathrm{p} . \mathrm{m}$. is likely to be adequate for fair-skinned Central Europeans. The advantages and disadvantages of sun exposure must be balanced, at least during summer, because excessive sun exposure is a potential risk factor for skin cancer [30]. Direct exposure to the sun is not recommended for infants younger than six months. Experiencing many severe sunburns up to young adulthood is considered a serious risk factor for skin cancer. Sun exposure is not recommended for people with skin type 1 (pale white 
skin, blue eyes, red hair) or with a history of sunburns or a history of skin cancer in the family.

\section{Recommended Vitamin D intakes in the general population}

\section{Neonates and infants (0-12 months):}

- vitamin D supplementation should be introduced from the first days of life, irrespective of nutritional option (breastfeeding or/and formula-based nutrition);

- supplementation of $400 \mathrm{IU} /$ day $(10.0 \mu \mathrm{g} /$ day) up to age 6 months;

- supplementation of 400-600 IU/day (10.0-15.0 $\mu \mathrm{g} /$ day) between 6 and 12 months of age depending on daily Vitamin D intake from diet.

\section{Children and adolescents (1-18 years):}

- supplementation of 600-1,000 IU/day (15.0-25.0 $\mathrm{gg} /$ day), depending on body weight, is recommended between September and April;

- supplementation of 600-1,000 IU/day (15.0-25.0 $\mu \mathrm{g} /$ day), depending on body weight, is recommended throughout the whole year, if sufficient skin synthesis of Vitamin D is not ensured in the summer.

\section{Adults ( $>18$ years) and the elderly:}

- supplementation of 800-2,000 IU/day (20.0-50.0 $\mu \mathrm{g} /$ day), depending on body weight, is recommended between September and April;

- supplementation of 800-2,000 IU/day (20.0-50.0 $\mu \mathrm{g} /$ day), depending on body weight, is recommended throughout the whole year, if sufficient skin synthesis of Vitamin D is not ensured in the summer;

- the elderly (65 years and above) should be supplemented with 800-2,000 IU/day (20.0-50.0 $\mu \mathrm{g} /$ day) throughout the whole year, because of the reduced efficacy of Vitamin D skin synthesis.

\section{Pregnant and breastfeeding women:}

- women who plan pregnancy should start/maintain Vitamin D supplementation as recommended for adults. Adequate Vitamin D intake before pregnancy should be ensured;

- vitamin D supplementation of 1,500-2,000 IU/day (37.5-50.0 $\mu \mathrm{g} /$ day) should begin at least from the second trimester of pregnancy. Gynaecologists/ /obstetricians should consider starting Vitamin D supplementation for pregnant women soon after pregnancy is confirmed;

- if feasible, periodical monitoring of serum $25(\mathrm{OH}) \mathrm{D}$ concentration should be done to define optimum dosage and to verify efficacy of supplementation. The goal of supplementation is to achieve and maintain $25(\mathrm{OH})$ D concentration of $30-50 \mathrm{ng} / \mathrm{mL}(75-125 \mathrm{nmol} / \mathrm{L})$.

\section{Recommended Vitamin D intakes in groups at risk of Vitamin D deficiency}

\section{Premature infants:}

- vitamin D supplementation should be introduced from the first days of life (as soon as enteral feeding is possible);

- supplementation of 400-800 IU/day (10-20 $\mu \mathrm{g} /$ day) until accomplishing the corrected gestational age of 40 weeks should be warranted; thereafter, the recommendations as for normal-term infants are adequate.

\section{Obese children and adolescents (BMI > 90th} percentile for age and gender using local reference in a given country):

- Supplementation of 1,200-2,000 IU/day (30-50 $\mu \mathrm{g}$ / /day), depending on severity of obesity, is recommended between September and April.

- Supplementation of 1,200-2,000 IU/day (30-50 $\mu \mathrm{g} /$ /day), depending on severity of obesity, is recommended throughout the whole year, if sufficient skin synthesis of Vitamin D is not ensured in the summer.

\section{Obese adults and the elderly (BMI 30+ $\mathrm{kg} / \mathrm{m2}$ ):}

- supplementation of 1,600-4,000 IU/day (40-100 $\mu \mathrm{g})$ day), depending on severity of obesity, is recommended throughout the whole year;

- sensible exposure to sunlight in the context of additional oral Vitamin D intake is safe.

\section{Night workers and dark-skinned adults:}

- supplementation of 1,000-2,000 IU/day (25-50 $\mu \mathrm{g} /$ /day), depending on body weight, is recommended throughout the whole year for dark-skinned persons;

- supplementation of 1,000-2,000 IU/day (25-50 $\mu \mathrm{g} /$ (day), depending on body weight, is recommended for night workers throughout the whole year.

\section{Recommended tolerable UL values for Vitamin $D$ intake in the general population}

The tolerable UL value is the highest average daily Vitamin D oral intake likely to pose no risk of adverse effects for Central European populations during growth and maturation, adulthood and ageing. The UL for Vitamin $\mathrm{D}$ does matter in healthy individuals, whereas at least two diseases should be considered as exceptions from the general rule, i.e.:

- Granulomatous conditions (e.g. sarcoidosis), with excessive extrarenal 1- $\alpha$-hydroxylase (CYP27B1) expression, excessive uncontrolled 1,25-dihydroxyVitamin D (calcitriol) production causing hypercalcemia at relatively low serum $25(\mathrm{OH}) \mathrm{D}$ concentration [33]; in granulomatous conditions, the 
recommended target for serum $25(\mathrm{OH}) \mathrm{D}$ concentration is approximately $25 \mathrm{ng} / \mathrm{mL}(62.5 \mathrm{nmol} / \mathrm{L})$ [31] .

- Genetic absence of, or defective, 24-hydroxylase (CYP24A1) activity (as in idiopathic infantile hypercalcemia, which can remain unnoticed until adulthood and cause nephrolithiasis in later life), a situation that compromises the ability of the kidneys or target cells to destroy 25-hydroxyVitamin D or calcitriol, leading to hypercalciuria and/or hypercalcemia at relatively 'normal' $25(\mathrm{OH}) \mathrm{D}$ concentrations [32]

The Panel of Experts adopted the European Food Safety Authority scientific opinion on the Tolerable Upper Intake Levels of Vitamin D for all relevant population groups, except obese adults and the elderly [27]. The highest average daily Vitamin D intakes likely to pose no risk of adverse effects are as follows:

- For neonates and infants, 1,000 IU/day (25 $\mu \mathrm{g} /$ day);

— For children aged 1-10 years, 2,000 IU/day (50 $\mu \mathrm{g} /$ /day)

- For children and adolescents aged 11-18 years, 4,000 IU/day (100 $\mu \mathrm{g} /$ day);

- For adults and the elderly with normal body weight, 4,000 IU/day (100 $\mu \mathrm{g} /$ day);

- For obese adults and obese elderly people, 10,000 IU/day $(250 \mu \mathrm{g} /$ day $)$;

- For both pregnant and breastfeeding women, 4,000 IU/day (100 $\mu \mathrm{g} /$ day).

\section{Recommended therapeutic doses for patients with verified Vitamin D deficiency}

\section{Assessment of Vitamin D status and diagnostic criteria}

The serum concentration of $25(\mathrm{OH}) \mathrm{D}$ - the main measurable circulating Vitamin D metabolite - indicates Vitamin D status. Total $25(\mathrm{OH}) \mathrm{D}$ concentration reflects delivery of Vitamin D from both cutaneous and oral sources. The $25(\mathrm{OH}) \mathrm{D}$ serum concentration is expressed in nanograms per millilitre or nanomoles per litre $(1 \mathrm{ng} / \mathrm{mL}=2.5 \mathrm{nmol} / \mathrm{L})$. Recent analytical methods are, in general, applied by fully automated platforms used in routine clinical chemistry laboratories. For routine/ /clinical 25(OH)D testing, we recommend methods that measure both $25(\mathrm{OH}) \mathrm{D}_{2}$ and $25(\mathrm{OH}) \mathrm{D}_{3}$, giving a total $25(\mathrm{OH}) \mathrm{D}$ serum concentration value, with an intra-assay coefficient of variation of less than $5 \%$ and an interassay coefficient of variation of less than $10 \%$. The best assays provide total $25(\mathrm{OH}) \mathrm{D}$ concentration, excluding a recently discovered metabolite, 3-epi- $25(\mathrm{OH}) \mathrm{D}_{3}[33,34]$.

The diagnostics thresholds defining concentrations of serum $25(\mathrm{OH}) \mathrm{D}$ approved in Central Europe are as follows:
- concentrations below $20 \mathrm{ng} / \mathrm{mL}$ (50 nmol/L) indicate Vitamin D deficiency, which should be treated medically;

- concentrations of $20 \mathrm{ng} / \mathrm{mL}(50 \mathrm{nmol} / \mathrm{L})$ up to $30 \mathrm{ng} / \mathrm{mL}$ (75 nmol/L) reflect a suboptimal Vitamin D status that calls for a moderate increase of Vitamin D daily dose;

- concentrations higher than $30 \mathrm{ng} / \mathrm{mL}$ (75 nmol/L) up to $50 \mathrm{ng} / \mathrm{mL}(125 \mathrm{nmol} / \mathrm{L})$ reflect adequate Vitamin D status; the supplementation scheme and dose should be maintained;

- concentrations higher than $50 \mathrm{ng} / \mathrm{mL}(125 \mathrm{nmol} / \mathrm{L})$ up to $100 \mathrm{ng} / \mathrm{mL}(250 \mathrm{nmol} / \mathrm{L})$ indicate a high Vitamin D supply; the supplementation dose can be maintained for lower concentrations of this range or moderately decreased for higher concentrations;

- concentrations higher than $100 \mathrm{ng} / \mathrm{mL}(250 \mathrm{nmol} / \mathrm{L})$ are risky for overall health outcomes and need reduction/cessation of Vitamin D supplementation until obtaining target $25(\mathrm{OH}) \mathrm{D}$ concentration;

- concentrations higher than $200 \mathrm{ng} / \mathrm{mL}(500$ $\mathrm{nmol} / \mathrm{L}$ ) are considered toxic and require cessation of Vitamin D supplementation until obtaining target $25(\mathrm{OH}) \mathrm{D}$ concentration; such people may need specific medical intervention to correct toxic effects.

\section{Indications for 25(OH)D testing}

There are various clinical circumstances and conditions, involving all age groups, in which serum $25(\mathrm{OH})$ $\mathrm{D}$ measurements are justified. Vitamin D deficiency accompanies e.g. renal or liver malfunctions, malabsorption, maldigestion syndromes and obesity, and it can coexist with various treatments (e.g. with anticonvulsants, glucocorticoids, ketoconazole). Untreated Vitamin D deficiency can significantly reduce the effectiveness of such underlying therapy or modify the course of a disease.

We recommend $25(\mathrm{OH}) \mathrm{D}$ testing in:

- patients with rickets, osteomalacia, musculoskeletal pain, propensity to falls, idiopathic and secondary osteoporosis including patients with osteoporotic fractures, and history of low-energy fractures of different origin;

- patients with calcium/phosphate metabolism abnormalities;

- patients with hyperparathyroidism;

- patients with prolonged glucocorticoid therapy at the dose of $7 \mathrm{mg}$ of prednisone per day or higher;

- patients taking anticonvulsant medications;

- patients taking ketoconazole;

- patients taking anti-AIDS medications (antiretroviral therapy); 
- patients with malabsorption syndromes (coeliac disease, Crohn's disease, past gastrointestinal bypass surgery, cystic fibrosis, inflammatory bowel disease);

- patients treated with long-lasting elimination diets implemented for the management of cow's milk allergy, lactose intolerance/hypolactasia; total parenteral nutrition; eating disorders;

- patients with chronic kidney disease stage 3-5 and kidney transplant recipients

- patients with hepatic failure and/or cholestasis;

- patients with granulomatous disorders (tuberculosis, sarcoidosis);

- patients with different types of cancer;

- patients with cardiovascular diseases, especially hypertension;

- patients with some chronic autoimmune diseases (multiple sclerosis, psoriasis, rheumatoid arthritis, dermatomyositis, lupus/SLE);

- patients admitted to hospital because of some infections (hepatitis $\mathrm{C}$, recurrent acute lower respiratory tract infection) and chronic allergic diseases such as atopic dermatitis or atopic asthma.

\section{Treatment}

Individuals with diagnosed Vitamin D deficiency require higher doses of Vitamin D than those recommended for the general population. The therapeutic dose in severe depletion should be 1,000-10,000 IU/ /day ( 50,000 IU/week), depending on the patient's age and body weight. Loading doses of 300,000 IU and higher are not recommended, even for the treatment of severe deficiency [35]. The duration of supplementation usually varies from 1-3 months, depending on the severity of Vitamin D deficiency. After a patient achieves the $25(\mathrm{OH}) \mathrm{D}$ concentration of $30-50 \mathrm{ng} / \mathrm{mL}(75-125 \mathrm{nmol} / \mathrm{L})$, a maintenance dose may be instituted. It is reasonable to reevaluate $25(\mathrm{OH}) \mathrm{D}$ concentration after 3-4 months and then to monitor semi-annually, especially with the coincidence of exacerbating factors such as obesity that need therapeutic doses covering the upper range of standard dosage. In cases with severe deficits, monitoring of serum calcium and phosphate concentrations, total alkaline phosphatase (ALP) activity and calciuria rate in spot urine $(\mathrm{Ca} / \mathrm{CR}$ ratio) may be desirable.

Analogues such as $1 \alpha-(\mathrm{OH}) \mathrm{D}_{3^{\prime}} 1 \alpha, 25(\mathrm{OH})_{2} \mathrm{D}_{3^{\prime}}$ 19-nor- $1 \alpha 25(\mathrm{OH})_{2} \mathrm{D}_{2^{\prime}}, 1 \alpha-(\mathrm{OH}) \mathrm{D}_{2^{\prime}}, 22$-oxa- $1 \alpha, 25(\mathrm{OH})_{2} \mathrm{D}_{3^{\prime}}$ 22-oxa- $1 \alpha, 25(\mathrm{OH})_{2} \mathrm{D}_{3^{\prime}}$, and others should not be used to manage Vitamin D deficiency. Analogues may be applied in disorders of Vitamin D hydroxylation associated with chronic renal disease.

\section{Recommended therapeutic doses of Vitamin D \\ (treatment duration lasting 1-3 months):}

- for neonates (i.e. younger than one month) with $25(\mathrm{OH}) \mathrm{D}$ concentration lower than $20 \mathrm{ng} / \mathrm{mL}$ (50 $\mathrm{nmol} / \mathrm{L}), 1,000 \mathrm{IU} /$ day $(25 \mu \mathrm{g} /$ day $)$

- for infants aged 1-12 months with $25(\mathrm{OH}) \mathrm{D}$ concentration lower than $20 \mathrm{ng} / \mathrm{mL}(50 \mathrm{nmol} / \mathrm{L})$, 1,000-3,000 IU/day (25-75 $\mu \mathrm{g} /$ day), depending on body weight

— for children and adolescents aged 1-18 years with $25(\mathrm{OH}) \mathrm{D}$ concentration lower than $20 \mathrm{ng} / \mathrm{mL}$ (50 $\mathrm{nmol} / \mathrm{L}), 3,000-5,000 \mathrm{IU} /$ day $(75-125 \mu \mathrm{g} /$ day), depending on body weight

- for adults and the elderly with $25(\mathrm{OH}) \mathrm{D}$ concentration lower than $20 \mathrm{ng} / \mathrm{mL}(50 \mathrm{nmol} / \mathrm{L}), 7,000-10,000$ IU/day (175-250 $\mu \mathrm{g} /$ day), depending on body weight, or 50,000 IU/week (1250 $\mu \mathrm{g} /$ week)

The algorithm summarises current recommendations.

\section{Discussion}

Recommendations for serum 25(OH)D concentrations and Vitamin D supplementation are based on studies of health outcomes with respect to either serum $25(\mathrm{OH}) \mathrm{D}$ concentrations or Vitamin Dintakes. Three types of observational studies deal with the analysis of health outcomes with respect to serum $25(\mathrm{OH}) \mathrm{D}$ concentrations:

- case-control studies that use serum $25(\mathrm{OH}) \mathrm{D}$ concentrations measured at the time of health outcome diagnosis;

- cohort studies that use serum 25(OH)D concentrations measured at the time of enrollment, with health outcome determined after several years of follow-up;

- cross-sectional studies that sample the population and examine correlations between serum $25(\mathrm{OH}) \mathrm{D}$ concentrations and health conditions

All three types of study are useful, but each has inconsistencies and different levels of evidence. The health condition in question may influence serum $25(\mathrm{OH}) \mathrm{D}$ concentration at the time of diagnosis. However, this possibility seems unlikely for health outcomes that are not known until diagnosed, such as cancer incidence, since there is a smooth, continuous change in cancer incidence rates with respect to follow-up time [36]. Serum $25(\mathrm{OH})$ D concentration at the time of enrollment in cohort studies may not be the concentration relevant to reducing risk of the health outcome. In addition, as serum $25(\mathrm{OH}) \mathrm{D}$ concentrations change over time, the longer the follow-up period, the lower the beneficial effect that is found [36, 37]. In cross-sectional studies, a health condition may considerably influence serum $25(\mathrm{OH}) \mathrm{D}$ concentration, for example for those 
Table II. Evidence of associations between serum 25(OH)D concentrations above $30 \mathrm{ng} / \mathrm{mL}$ and optimal health

Tabela II. Przykłady badań dokumentujących związek między stężeniem 25(OH)D powyżej 30 ng/ml a optymalizacją stanu zdrowia

\begin{tabular}{|c|c|c|c|c|}
\hline Health outcome & Study type/design & $25(\mathrm{OH}) \mathrm{D}$ concentrations studied & Finding & Reference \\
\hline $\begin{array}{l}\text { Breast cancer } \\
\text { incidence }\end{array}$ & $\begin{array}{l}\text { Meta-analysis of five case- } \\
\text { control studies of breast cancer } \\
\text { incidence }\end{array}$ & $30 \mathrm{ng} / \mathrm{mL}$ vs. $10 \mathrm{ng} / \mathrm{mL}$ & $\mathrm{OR}=0.44$ & Grant [46] \\
\hline $\begin{array}{l}\text { Colorectal cancer } \\
\text { incidence }\end{array}$ & $\begin{array}{l}\text { Meta-analysis of ten case-control } \\
\text { and cohort studies of colorectal } \\
\text { cancer incidence }\end{array}$ & $30 \mathrm{ng} / \mathrm{mL}$ vs. $5 \mathrm{ng} / \mathrm{mL}$ & $\mathrm{OR}=0.40$ & Grant [4] \\
\hline CVD & $\begin{array}{l}\text { Prospective study with mean } \\
\text { follow-up time of } 1.3 \text { years }\end{array}$ & $30 \mathrm{ng} / \mathrm{mL}$ vs. $<15 \mathrm{ng} / \mathrm{mL}$ & $\begin{array}{c}\text { Adjusted } \mathrm{HR}=1.62(95 \% \mathrm{Cl} \text { ， } \\
1.38-1.89)\end{array}$ & Anderson et al. [5] \\
\hline CVD & $\begin{array}{l}\text { Random-effects meta-analysis of } \\
\text { nine prospective studies with } \\
<10 \text { years of follow-up }\end{array}$ & Lowest vs. highest & $\begin{array}{l}\text { Pooled relative risk }=1.86 \\
(95 \% \mathrm{Cl}, 1.47-2.34) \text { for } \\
\text { incident CVD }\end{array}$ & Wang et al. [6] \\
\hline $\begin{array}{l}\text { Type } 2 \text { diabetes } \\
\text { mellitus }\end{array}$ & $\begin{array}{l}\text { Meta-analysis of seven } \\
\text { prospective studies }\end{array}$ & $>25 \mathrm{ng} / \mathrm{mL}$ vs. $<14 \mathrm{ng} / \mathrm{mL}$ & $\begin{array}{c}\mathrm{RR}=0.57(95 \% \mathrm{Cl} \\
0.43-0.76)\end{array}$ & Mitri et al. [8] \\
\hline $\begin{array}{l}\text { Type } 2 \text { diabetes } \\
\text { mellitus, }\end{array}$ & $\begin{array}{c}\text { Prospective observational } \\
\text { study with a mean follow-up } \\
\text { of } 2.7 \text { years in patients with } \\
\text { prediabetes }\end{array}$ & $30.1 \mathrm{ng} / \mathrm{mL}$ vs. $12.8 \mathrm{ng} / \mathrm{mL}$ & $\begin{array}{c}\mathrm{HR}=0.72(95 \% \mathrm{Cl} \\
0.56-0.90)\end{array}$ & Pittas et al. [10] \\
\hline $\begin{array}{l}\text { Cognitive } \\
\text { impairment }\end{array}$ & $\begin{array}{l}\text { Elderly women older than } 70 \\
\text { years }\end{array}$ & $<10 \mathrm{ng} / \mathrm{mL}$ vs. $>30 \mathrm{ng} / \mathrm{mL}$ & $\begin{array}{c}\mathrm{OR}=1.60(95 \% \mathrm{Cl} \\
1.05-2.42)\end{array}$ & Slinin et al. [47] \\
\hline Cognitive decline & $\begin{array}{l}\text { Elderly women older than } 70 \\
\text { years; cognitive decline } 2-4 \\
\text { years after baseline }\end{array}$ & $<10 \mathrm{ng} / \mathrm{mL}$ vs. $>30 \mathrm{ng} / \mathrm{mL}$ & $\begin{array}{l}\mathrm{OR}=1.58(95 \% \mathrm{Cl}, 1.12- \\
2.22) \text { for }>1-\sigma \text { cognitive } \\
\text { decline from mean }\end{array}$ & Slinin et al. [47] \\
\hline Hip fracture & Pooled analysis of RCTs & $\begin{array}{l}\text { Highest Vitamin D intake } \\
\text { (median, } 800 \text { IU daily; range, } \\
792-2,000 \text { ) vs. lowest }\end{array}$ & $\begin{array}{c}\mathrm{HR}=0.70(95 \% \mathrm{Cl} \\
0.58-0.86)\end{array}$ & $\begin{array}{l}\text { Bischoff-Ferrari et } \\
\text { al. [43] }\end{array}$ \\
\hline $\begin{array}{l}\text { Mortality, } \\
\text { all-cause }\end{array}$ & $\begin{array}{l}\text { Meta-analysis of } 11 \text { prospective } \\
\text { studies }\end{array}$ & $\begin{array}{c}\text { Minimum RR near } 30-35 \mathrm{ng} / \mathrm{mL} \\
25(\mathrm{OH}) \mathrm{D} \text { vs. lowest } 25(\mathrm{OH}) \mathrm{D}\end{array}$ & $\begin{array}{l}\text { Relative risk }=0.71(95 \% \mathrm{Cl}, \\
0.50-0.91)\end{array}$ & Zittermann et al. [48] \\
\hline $\begin{array}{l}\text { Respiratory infections, } \\
\text { acute viral }\end{array}$ & Infections in autumn/winter & $>38 \mathrm{ng} / \mathrm{mL}$ vs. $<38 \mathrm{ng} / \mathrm{mL}$ & $\begin{array}{c}\mathrm{RR}=0.51(95 \% \mathrm{Cl} \\
0.25-0.84)\end{array}$ & Sabetta et al. [49] \\
\hline
\end{tabular}

$\mathrm{Cl}$ — confidence interval; $\mathrm{CVD}$ — cardiovascular disease; HR — hazard ratio; $\mathrm{OR}$ — odds ratio; $\mathrm{RR}$ — risk ratio

staying indoors due to an illness. Despite several limitations of these studies, they form the primary basis of our understanding of the benefits of Vitamin D for many health outcomes. The results of such studies become more reliable in the context of meta-analyses, which combine all similar using a weighting scheme based on the number of cases in each study.

In addition, ecological studies based on geographic or seasonal variations are meaningful, especially in generating hypotheses, because solar ultraviolet-B is the primary source of Vitamin D for $90 \%$ of the population. Examples include geographical variation for many types of cancer [38, 39] and seasonal variation in cancer incidence [40]. A study on cancer incidence with respect to occupation in Nordic countries provides well-balanced evidence that solar UVB reduces risk of many types of cancer [41]. No mechanism other than Vitamin D production has been proposed to explain the findings from ecological studies of cancer incidence and/or mortality rates with respect to solar UVB doses across countries. Furthermore, there is much additional support elsewhere for the role of Vitamin D in reducing the risk of cancer $[3,4]$.

Researchers conduct randomised controlled trials (RCTs) to overcome the problems of observational studies. RCTs, however, also demonstrate several methodological issues.

According to Lappe and Heaney [42], a well-conducted RCT should:

- start with a general idea of the relation between serum $25(\mathrm{OH}) \mathrm{D}$ concentration and health outcome;

- enroll people near the low end of $25(\mathrm{OH}) \mathrm{D}$ concentration;

- give those in the treatment arm enough Vitamin D to increase serum $25(\mathrm{OH}) \mathrm{D}$ concentration to the point that little additional benefit is expected;

- measure serum 25(OH)D concentration both at time of enrollment and after supplementation. 
Furthermore, as many other sources of Vitamin D exist, studies have to control them all. Unfortunately, most RCTs conducted to date have not followed these guidelines. Several investigations have considered a daily Vitamin D dose of only 400 IU, which confers little health benefit. Nonetheless, a few studies have confirmed some of the findings from observational studies, such as for fractures [43], all-cancer incidence [44], and type A influenza [45], however, this was not consistently shown in all RCTs either.

While RCTs would provide an extra level of confidence to the Vitamin D recommendations, it seems that there is sufficient evidence of the beneficial effects of Vitamin D intake and/or production with very limited adverse effects that the general health of the population would be significantly improved by adopting the recommendations proposed in this paper.

Table II presents an overview of findings from the journal literature regarding health outcomes as a function of serum $25(\mathrm{OH}) \mathrm{D}$ concentration or oral Vitamin D intake. The examples chosen were generally derived from recently published papers, with an emphasis on meta-analyses.

\section{Conclusions}

There is an urgent need to improve the Vitamin D status of children, adolescents, adults and the elderly. The present paper offers elaborated consensus on supplementation guidance and population strategies for Vitamin D in Central Europe. Prophylaxis of Vitamin D deficiency should be included in the priorities of physicians, medical professionals and healthcare policy-makers.

It is postulated to adopt our practical guidelines on vitamin D supplementation to population of Central Europeans

\section{References}

1. Holick MF Resurrection of vitamin D deficiency and rickets. J Clin Invest 2006; 116: 2062-2072.

2. Garland CF, French CB, Baggerly LL et al. Vitamin D supplement doses and serum 25-hydroxyvitamin $\mathrm{D}$ in the range associated with cancer prevention. Anticancer Res 2011; 31: 617-622.

3. Garland CF, Gorham ED, Mohr SB et al. Vitamin D for cancer prevention: Global perspective. Ann Epi 2009; 19: 468-483.

4. Grant WB. Relation between prediagnostic serum 25-hydroxyvitamin D level and incidence of breast, colorectal, and other cancers. J Photochem Photobiol B: Biol, 2010; 101: 130-136.

5. Anderson JL, May HT, Horne BD et al for the Intermountain Heart Collaborative (IHC) Study Group: Relation of vitamin D deficiency to cardiovascular risk factors, disease status, and incident events in a general healthcare population. Am J Cardiol 2010; 106: 963-968.

6. Wang L, Song Y, Manson JE et al. Circulating 25-hydroxy-vitamin D and risk of cardiovascular disease: A meta-analysis of prospective studies. Circ Cardiovasc Qual Outcomes 2012; 1; 5: 819-829.

7. Pilz S, Tomaschitz A, Marz W et al. Vitamin D, cardiovascular disease and mortality. Clin Endocrinol (Oxf) 2011; 75: 575-584.

8. Mitri J, Muraru MD, Pittas AG. Vitamin D and type 2 diabetes: a systematic review. Eur J Clin Nutr 2011; 65: 1005-1015.

9. Khan H, Kunutsor S, Franco OH et al. Vitamin D, type 2 diabetes and other metabolic outcomes: a systematic review and meta-analysis of prospective studies. Proc Nutr Soc 2012; 30: 1-9.
10. Pittas AG, Nelson J, Mitri J et al. Diabetes Prevention Program Research Group. Plasma 25-hydroxyvitamin D and progression to diabetes in patients at risk for diabetes: an ancillary analysis in the Diabetes Prevention Program. Diabetes Care 2012; 35: 565-573.

11. Scragg R, Sowers M, Bell C. Serum 25-hydroxyvitamin D, ethnicity, and blood pressure in the Third National Health and Nutrition Examination Survey. Am J Hypertens 2007; 20: 713-719.

12. Pittas AG, Chung $M$, Trikalinos $T$ et al. Systematic review: Vitamin D and cardiometabolic outcomes. Ann Intern Med 2010; 152: 307-314.

13. Burgaz A, Orsini N, Larsson SC et al. Blood 25-hydroxyvitamin D concentration and hypertension: a meta-analysis. J Hypertens 2011; 29: 636-645.

14. Littorin B, Blom P, Schölin A et al. Lower levels of plasma 25-hydroxyvitamin $\mathrm{D}$ among young adults at diagnosis of autoimmune type 1 diabetes compared with control subjects: results from the nationwide Diabetes Incidence Study in Sweden (DISS). Diabetologia 2006; 49: 2847-2852.

15. Raghuwanshi A, Joshi SS, Christakos S. Vitamin D and multiple sclerosis. J Cell Biochem 2008; 105: 338-343.

16. Pappa HM, Gordon CM, Saslowsky TM et al. Vitamin D status in children and young adults with inflammatory bowel disease. Pediatrics 2006; 118: 1950-1961.

17. Hyppönen E, Boucher BJ, Berry DJ, Power C: 25-hydroxyvitamin D, IGF1 , and metabolic syndrome at 45 years of age: a cross-sectional study in the 1958 British Birth Cohort. Diabetes 2008; 57: 298-305.

18. Boucher BJ. Is vitamin D status relevant to metabolic syndrome? Dermatoendocrinol 2012; 4: 212-224.

19. Hewison M. Vitamin D and immune function: autocrine, paracrine or endocrine? Scand J Clin Lab Invest (Suppl.) 2012; 243: 92-102.

20. Llewellyn DJ, Lang IA, Langa KM et al. Vitamin D and risk of cognitive decline in elderly persons. Arch Intern Med 2010; 170: 1135-1141.

21. Charzewska J, Chlebna-Sokol D, Chybicka A et al. Prophylaxis of vitamin D deficiency-Polish recommendation 2009. Endokrynol Pol 2010; 61: 228-232.

22. Takacs I, Benko I, Toldy E et al. Hungarian consensus regarding the role of vitamin $\mathrm{D}$ in the prevention and treatment of diseases. Orv Hetil 2012; 153 (Suppl.): 5-26.

23. German Nutrition Society. New reference values for vitamin D. Ann Nutr Metab 2012; 60: 214-246.

24. IOM (Institute of Medicine): Dietary reference intakes for calcium and vitamin D. Washington (DC): National Academies Press (US); 2011.

25. Holick MF, Binkley NC, Bischoff-Ferrari HA et al., Endocrine Society: Evaluation, treatment, and prevention of vitamin D deficiency: an Endocrine Society clinical practice guideline. J Clin Endocrinol Metab 2011; 96: 1911-1930.

26. Dawson-Hughes B, Mithal A, Bonjour JP et al. IOF position statement: vitamin D recommendations for older adults. Osteoporos Int 2010; 21: 1151-1154.

27. EFSA Panel on Dietetic Products, Nutrition and Allergies (NDA): Scientific opinion on the tolerable upper intake level of vitamin D. EFSA Journal 2012; 10: 2813: 1-45.

28. Holick MF. Vitamin D and sunlight: strategies for cancer prevention and other health benefits. Clin J Am Soc Nephrol 2008; 3: 1548-1554.

29. Krzyscin JW, Jaroslawski J, Sobolewski PS. A mathematical model for seasonal variability of vitamin D due to solar radiation. J Photochem Photobiol B 2011; 5; 105: 106-112.

30. Mason RS, Reichrath J. Sunlight Vitamin D and Skin Cancer. Anticancer Agents Med Chem 2013; 13: 83-97.

31. Kavathia D, Buckley JD, Rao D et al. Elevated 1, 25-dihydroxyvitamin D levels are associated with protracted treatment in sarcoidosis. Respir Med 2010; 104: 564-570.

32. Schlingmann KP, Kaufmann M, Weber S et al. Mutations of CYP24A1 and Idiopathic Infantile Hypercalcemia. New Engl J Med 2011; 365: $410-421$.

33. Singh RJ, Taylor RL, Reddy GS et al. C-3 epimers can account for a significant proportion of total circulating 25-hydroxyvitamin $D$ in infants, complicating accurate measurement and interpretation of vitamin D status. J Clin Endocrinol Metab 2006; 91: 3055-3061.

34. Lensmeyer G, Poquette M, Wiebe D et al. The C-3 epimer of 25-hydroxyvitamin D3 is present in adult serum. J Clin Endocrinol Metab 2012; 97: 163-168.

35. Sanders KM, Stuart AL, Williamson EJ et al. Annual high-dose oral vitamin D and falls and fractures in older women: a randomized controlled trial. JAMA 2010; 12; 303: 1815-1822.

36. Grant WB. Effect of interval between serum draw and follow-up period on relative risk of cancer incidence with respect to 25 -hydroxyvitamin D level; implications for meta-analyses and setting vitamin $\mathrm{D}$ guidelines. Dermatoendocrinol 2011; 3: 199-204.

37. Grant WB. Effect of follow-up time on the relation between prediagnostic serum 25-hydroxyitamin D and all-cause mortality rate. Dermatoendocrinol 2012; 4: 198-202

38. Grant WB. Ecological studies of the UVB-vitamin D-cancer hypothesis. Anticancer Res 2012; 32: 223-236. 
39. Lin SW, Wheeler DC, Park Y et al. Prospective study of ultraviolet radiation exposure and risk of cancer in the U.S. Int J Cancer 2012; 131: E1015-1023.

40. Cannell JJ, Vieth R, Umhau JC et al. Epidemic influenza and vitamin D. Epidemiol Infect 2006; 134: 1129-1240.

41. Grant WB. Role of solar UV irradiance and smoking in cancer as inferred from cancer incidence rates by occupation in Nordic countries. Dermatoendocrinol 2012; 4: 203-211.

42. Lappe JM, Heaney RP. Why randomized controlled trials of calcium and vitamin D sometimes fail. Dermatoendocrinol 2012; 4: 95-100.

43. Bischoff-Ferrari HA, Willett WC, Orav EJ et al. A pooled analysis of vitamin D dose requirements for fracture prevention. N Engl J Med 2012; 367: 40-49.

44. Lappe JM, Travers-Gustafson D, Davies KM et al. Vitamin D and calcium supplementation reduces cancer risk: results of a randomized trial. Am J Clin Nutr 2007; 85: 1586-1591.
45. Urashima M, Segawa T, Okazaki M et al. Randomized trial of vitamin D supplementation to prevent seasonal influenza A in schoolchildren. Am J Clin Nutr 2010; 91: 1255-1260.

46. Grant WB. A review of the evidence regarding the solar ultraviolet-Bvitamin D-cancer hypothesis. Standardy Med 2012; 9: 610-619.

47. Slinin Y, Paudel M, Taylor BC et al. Study of Osteoporotic Fractures Research Group: Association between serum 25(OH) vitamin D and the risk of cognitive decline in older women. J Gerontol A Biol Sci Med Sci 2012; 67: 1092-1098.

48. Zittermann A, Iodice S, Pilz S et al. Vitamin D deficiency and mortality risk in the general population: A meta-analysis of prospective cohort studies. Am J Clin Nutr 2012; 95: 91-100.

49. Sabetta JR, DePetrillo P, Cipriani RJ et al. Serum 25-hydroxyvitamin D and the incidence of acute viral respiratory tract infections in healthy adults. PLoS One 2010; 5: e11088. 